\title{
Plural policing: a Magyarországon és külföldön müködö, biztonság megteremtéséért felelös szervek összehasonlítása
}

\section{SCHMIDT Laura ${ }^{1}$}

\begin{abstract}
A cikk célja bemutatni, hogy kik felelösek Magyarországon, illetve külföldön a rendőrség mellett biztonságunk megteremtéséért. A Magyarországon múködő rendőrséget, az önkormányzati rendészetet, az egyes rendészeti feladatokat ellátókat, a társadalmi önkéntes búnmegelözési egyesületeket, valamint a magánbiztonsági szervezeteket hasonlítom össze az Egyesült Királyságban lévő szervekkel, de bemutatom a dél-afrikai köztársaságbeli, illetve a holland szerveket is.

A kiválasztott országokban a néhány eltérés mellett látható, hogy hasonlóságok mutatkoznak például az önkormányzati rendészet és a társadalmi önkéntes bünmegelőzési egyesületek feladatai között is.

A plural policing rendszerének egyre nagyobb szerepe van külföldön és hazánkban is a biztonság fenntartásában és a büncselekmények megelözésében, így fontos, hogy minél több információnk legyen ennek a rendszernek a felépítéséről, müködéséröl.
\end{abstract}

Kulcsszavak: biztonság, magánbiztonság, rendvédelmi szervek, plural policing

\section{Bevezetés}

A biztonság témaköre mindannyiunk számára lényeges és fontos. Úgy gondolom, hogy rendkívül hasznos, ha egy átfogó tudásunk van azokról a hazai és külföldi szervezetekről, akik a rendőrség mellett a biztonságunk megteremtéséért felelősek.

Célom a biztonság és a plural policing fogalom definiálása mellett a magyarországi és néhány külföldi országban működő, rendőrség és a rendőrség mellett dolgozó szervezetek bemutatása, valamint összehasonlítása.

Az összehasonlításhoz kiválasztott országok Magyarország mellett az Egyesült Királyság, a Dél-afrikai Köztársaság és Hollandia. Az országok kiválasztása az alapján történt, hogy az Egyesült Királyságban és a Hollandiában müködő rendszerekről sok angol nyelvű cikk található, míg a Dél-afrikai Köztársaságban a magas bűnözési ráta mellett

SCHMIDT Laura, doktoranda, Nemzeti Közszolgálati Egyetem Rendészettudományi Doktori Iskola

Laura SCHMIDT, PhD student, University of Public Service, Faculty of Law Enforcement

https://orcid.org/0000-0002-4641-0457; mslauraschmidt@gmail.com 
sok közösség által indítványozott program figyelhető meg, amelyek nagyban befolyásolják a búnügyi statisztikákat helyi szinten, és szintén angolul olvashatóak az ezekről szóló cikkek is.

Az összehasonlítást az országokban müködő rendőrségek szervezeti felépítésének leírásával kezdem, amely során kitérek azokra az egységekre is, amelyek a rendőrök munkáját támogatják a rendőrség szervezetén belül. Az önkormányzati rendészetet és az egyes rendészeti feladatokat ellátókat is bemutatom, a Magyarországon megtalálható közterület-felügyelet, az Egyesült Királyságban müködő közösségi támogató tisztek, valamint a Hollandiában található több hasonló szerepkört betöltő szervezet segítségével. Ezt követően a társadalmi önkéntes bűnmegelőzési egyesületekről, a bemutatott országokban múködő polgárőrségről olvashatunk, mielőtt a magánbiztonság intézményét tárgyaljuk.

\section{A biztonság definíciója}

A biztonságot sokféleképpen lehet definiálni. A magyar nyelv értelmező szótára szerint: „A biztonság a dolgoknak, életviszonyoknak olyan rendje, olyan állapot, amelyben kellemetlen meglepetésnek, zavarnak, veszélynek nincs vagy alig van lehetősége, amelyben ilyentől nem kell félni."2 Egy átlagpolgár valószínű a közbiztonságra, a szociális biztonságra asszociálna erről a szóról.

A biztonság szó a latin sine cura kifejezésből származik, amelyet úgy lehetne lefordítani, hogy „gond nélkül”. ${ }^{3}$ Az évek folyamán a biztonság kifejezés leginkább akkor került szóba, amikor különböző háborúkról, fegyveres erők alkalmazásáról volt szó. Ez alapján az állam jelentős szerepet kap a fogalom definiálásánál.

A hidegháborút követően azonban egyre nagyobb népszerüségnek örvendett a humán biztonság fogalma, amelynek legfontosabb elve, hogy az állam helyett az egyén álljon a középpontban. ${ }^{4}$ Ez a hozzáállás olyan emberi szükségleti tényezőket is biztonságra való fenyegetésnek tekint, mint a környezetszennyezés vagy az éhínség. A kritikusok legfőbb problémája, hogy túl széles lett így a veszélyek listája, amiben az elemek nincsenek priorizálva sem.

Fontos kiemelni, hogy ebben a cikkben a biztonság fogalmának használata alatt a közbiztonság fogalmát értjük.

A biztonság fogalmának megértése azért is fontos feladat, mert ennek megteremtése nemcsak az állam feladata, de a társadalom bevonását is megkívánja. A rendészet célkitűzése, hogy segítse az állam belső rendjének, illetve a közbiztonságnak a megtartását, amelyhez jogosult akár legitim fizikai erőszak használatára is. ${ }^{5}$ Mindez magában

\footnotetext{
Biztonság - A magyar nyelv értelmező szótára. Magyar Tudományos Akadémia Nyelvtudományi Intézet, 1959.

Gazdag Ferenc - Tálas Péter: A biztonság fogalmának határairól. Nemzet és Biztonság, 1. (2008), 3-10. 3.

Péczeli Anna: A humán biztonság elmélete és gyakorlata Kanada és Japán példáján. 2012.

Christián László: Rendészeti szervek. In Jakab András - Fekete Balázs (szerk.): Internetes Jogtudományi Enciklopédia. Alkotmányjog rovat, 2018. [7].
} 
foglalja a polgárok értékeinek védelmét, illetve az ezeket veszélyeztető jogsértő tevékenységek megelőzését, megakadályozását.

Mivel a biztonság megteremtése önmagában is egy komplex feladat, a rendőrség mellett nemcsak rendvédelmi szervek, hanem más piaci és civil szervek is hozzájárulnak ennek fenntartásához. A következőkben a Magyarországon, az Egyesült Királyságban, a Dél-afrikai Köztársaságban és a Hollandiában múködő, a biztonság megteremtéséért felelős szervek rövid bemutatása es összehasonlítása olvasható.

\subsection{A plural policing (nodal policing) definíciója}

A veszélyhelyzetek összetettségét és mennyiségét tekintve a rendőrség önállóan nem tud ellátni minden biztonsággal kapcsolatos feladatot. Szükség van a rendvédelmi szervekkel együttmúködő önkormányzatokra, magánbiztonsági vállalkozásokra, illetve civil önvédelmi szervezetekre is. ${ }^{6}$ Ezt a rendszert hívják plural policingnek.

Fontos megemlíteni, hogy ez a rendszer nem állítja prioritási sorrendbe egyik olyan szervezetet sem, amely a biztonság védelmének feladatát látja el. ${ }^{7}$

\section{A magyarországi és a külföldi példák összehasonlítása}

A következőkben a rendőrség, az önkormányzati rendészet és egyes rendészeti feladatokat ellátók, a társadalmi önkéntes bűnmegelőzési egyesületek, illetve a magánbiztonság területén szeretném bemutatni az összehasonlítást az országok között.

\subsection{A rendörségek összehasonlitása}

Az 1994. évi XXXIV. a Rendőrségről szóló törvény 1. § (1) bekezdése alapján a magyar rendőrség feladata az Alaptörvényben meghatározott feladatok elvégzése, valamint a határforgalom ellenőrzése, a terrorizmus elleni küzdelem, az ebben a törvényben meghatározott bűnmegelőzési, bűnfelderítési célú ellenőrzés, a bűncselekményből származó vagyon visszaszerzése és az idegenrendészeti és menekültügyi feladatok ellátása. ${ }^{8}$ Ennek a cikknek a szempontjából fontos kiemelni még a törvény 2 . $§(2)$ bekezdésének c) alpontját, amely azt állapítja meg, hogy a rendőrség feladatának ellátása során támogatja a helyi önkormányzatoknak és az állampolgárok közösségeinek

\footnotetext{
Christián (2019) i. m. [10].

Adam Crawford et alii: Plural policing: The mixed economy of visible patrols in England and Wales. Bristol, Policy Press, 2005. 4.

1994. évi XXXIV. törvény a Rendőrségről 1. § (1) bek.
} 
a közbiztonság javítására irányuló önkéntes tevékenységét, ezzel is hozzájárulva az önkormányzatok, illetve a közösség szélesebb körú bevonására. ${ }^{9}$

A rendőrség mint állami, fegyveres rendvédelmi szerv müködik, és a kormány a rendészetért felelős miniszter útján irányítja ezt. ${ }^{10}$ Magyarországon négy szerv alkotja a rendőrséget, az Országos Rendőr-főkapitányság (az általános rendőrségi feladatok ellátására létrehozott szerv), a Nemzeti Védelmi Szolgálat (a belső búnmegelőzési és bűnfelderítési feladatokat ellátó szerv), a Terrorelhárítási Központ (a terrorizmust elhárító szerv), valamint az Országos Idegenrendészeti Főigazgatóság (az idegenrendészeti szerv). ${ }^{11}$

A rendőr hivatalos személynek minősül, és széles körű jogosultságokkal rendelkezik. A rendőrök munkájuk végzése közben használhatnak bizonyos kényszerítőeszközöket, mindezt szükséges és arányos mértékben.

$\mathrm{Az}$ Egyesült Királyságban ezzel szemben úgynevezett területi rendőrségek (territorial police) múködnek, amelyek egy vagy több megyét fednek le, kivéve a londoni rendőrséget. ${ }^{12}$ Összesen 39 rendőrség mủködik Angliában és 4 található Walesben. Skóciában csak egy rendőrség (Police Scotland) felel a helyiek biztonságáért 2013 óta. Észak-Írországban szintén egy központi rendőrség (Police Service of Northern Ireland) van, amely lefedi az egész területet.

A területi rendőrségek természetesen folyamatos kapcsolatban állnak egymással és a különböző rendőrségeken belül megtalálhatóak olyan részlegek is, amelyek állami szinten látják el a feladatukat, nem csak területi szinten.

$\mathrm{Az}$ 1994-es a rendőrségről és a békebíróságokról szóló brit törvény (Police and Magistrates' Courts Act) több lehetőséget ad a rendőrségnek különböző szolgáltatások harmadik félnek való nyújtására, amelyre példa a rendőrtisztek idejének a szerződéses alapú kiszervezése. ${ }^{13} \mathrm{~A}$ brit rendőrségek ezt egyre nagyobb mértékben ki is használják, például labdarúgó-mérkőzések biztosításánál, többek közt a saját bevételek növelése céljából. ${ }^{14}$ Angliában és Walesben a helyi sajátosságok és a rangidős tisztek hozzáállásának függvényében más és más mértékben van lehetősége a rendőrségeknek ennek a törvény által biztosított lehetőségnek a kihasználására. Azonban ezekben az esetekben a múveleti felelősség ugyanúgy a rendőrtisztek feljebbvalóinak kezében van (ez leginkább a rendőrfőnököt jelenti), ez a felelősség nem hárul át a megbízó részére.

Fontos megemlíteni még az 1998-as brit rendőrségi törvényt (Crime and Disorder Act), amely bevezette az antiszociális viselkedésről szóló szabályt. ${ }^{15}$ Ez a szabály hasonló, mint Magyarországon a rendőrségről szóló törvény már említett bekezdése az önkormányzatok, illetve a közösség közbiztonság javítására való szélesebb körű bevonása. Ennek a szabálynak a bevezetése kötelezi a rendőrségeket, illetve a helyi

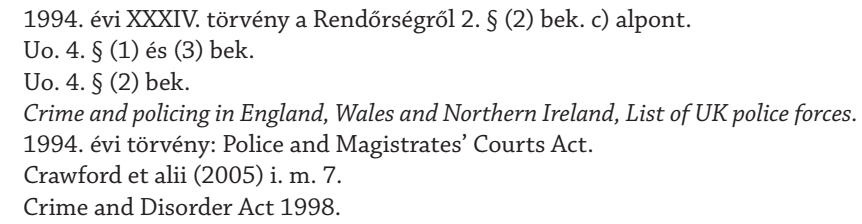


szerveket, hogy bűnmegelőző és -csökkentő partnerkapcsolatokat alakítsanak ki (úgynevezett $(D R P-\mathrm{k})$. Ez fontos alapja az Egyesült Királyságban müködő plural policing intézményének.

A területi rendőrségek mellett megtalálhatóak az Egyesült Királyságban az állami szinten működő bűnüldöző hatóságok is, mint például a Nemzeti Bűnüldözési Ügynökség (National Crime Agency), amely elsősorban a szervezett bủnözés ellen harcol, vagy a Nagy-Britanniában működő úgynevezett közlekedési rendőrség (British Transport Police), akik az ország vasútvonalain biztosítják a biztonságot. Többek között ők felelnek a londoni metróhálózat biztonságáért is. ${ }^{16} \mathrm{Az}$ ő csapatukat nemcsak rendőrök, hanem a rendőrség más alkalmazottjai, közösségi támogató tisztek (police community support officer) és polgárőrök (special constable) is alkotják.

Esti járatokon többször látni őket, de utazások során megfigyelhető, hogy egy közvetlen telefonszám is el van helyezve minden vasúti kocsiban, amelyre akár sms-t is lehet írni, ha valaki gyanús viselkedést észlel az utazása során.

A metrókon civil ruhás járőrök is vannak, akik a gyanús, illetve illetlen viselkedést próbálják meg kiszúrni. Ez a módszer a szexuális bűncselekmények megelőzésénél is hasznos lehet, amely esetek előfordulása a londoni metróhálózaton sajnos a mai napig is aktuális problémát jelentenek.

Ezzel szemben Hollandiában, 2013-ban az addig múködő 26 területi rendőrség egybeolvadt, amelynek eredményeképp egy nemzeti rendőrség jött létre. ${ }^{17}$ Ennek következményeképpen egy rendkívül centralizált rendvédelmi szerv alakult meg.

A holland nemzeti rendőrség 10 körzeti egységből, egy központi egységből és egy rendőrséget ellátó központból áll. ${ }^{18}$

A központi egység feladatai közé tartozik többek között a jelentősebb múveletek ellenőrzése, támogatása és koordinálása; a szervezett bűnözés elleni harc nemzeti és nemzetközi szinten; a királyi család és más kiemelt személyek védelmének az ellátása; a vasúti, vízi és légi közlekedés biztosítása; valamint a súlyos erőszak és terrorizmus elleni harc is (ennek végzésére egy külön részleg is múködik).

A saját feladatain kívül, a központi egység olyan feladatok ellátását is elvégzi, amelyek a körzeti egységek támogatására irányulnak.

A 10 körzeti egység a területi eloszlás alapján több kisebb csapatból tevődik össze és különböző környékek, városok és régiók biztonságáért felelős. Ők a térség alapvető rendőri szolgáltatásait látják el, mint például a járőrözés, nyomozói tevékenységek folytatása, segítségnyújtás vészhelyzetekben vagy akár közlekedési problémák megoldása.

A rendőrséget ellátó központ a körzeti egységek üzemeltetését biztosítja, itt található például a pénzügyi részleg vagy a humánerőforrás-menedzsment, így hozzájárulva ahhoz, hogy a körzeti egységeknek több ideje legyen a múveleti feladatok ellátására.

\footnotetext{
16 British Transport Police.

17 Ronald van Steden et alii: The many faces of nodal policing: Team play and improvisation in Dutch community safety. Security Journal, 29. (2016), 3. 327-339.

18 Organisation of the Dutch police. Government of the Netherlands.
} 
A hollandoknál 1990 óta úgynevezett rendőr járőrök (politiesurveillant) is segítik a rendőrség munkáját, akiknek a feladata, hogy extra megfigyelést biztosítsanak, így hozzájárulva többek között a közösség szubjektív biztonságérzetéhez. ${ }^{19}$

A Dél-afrikai Köztársaság az apartheid idején egy rendőrállamként müködött. ${ }^{20} \mathrm{Na}$ gyon kevés különbség volt a rendőrség és a hadsereg között. Azonban 1994 után bekerült a köztudatba a közösségi rendfenntartás fogalma, és ennek hatására sokkal több figyelem irányult a közösségi és a privát bűnmegelőzés kapcsolatára. Ennek ellenére, a nagyon magas bűnözési ráta rengeteg kihívást állít a rendőrség és az állampolgárok elé is.

A dél-afrikai rendőrség egy központi egységként múködik, amely az egész Délafrikai Köztársaság biztonságáért felelős. ${ }^{21}$ Fontos célkitǔzésnek tartja a közösség bevonását a biztonságos környezet megteremtése során. A rendőrség megnövekedett jelenlétével próbálja felhozni azokat a területeket, amelyek különösen érintettek a bűncselekmények elkövetésének szempontjából. Csakúgy, mint Hollandiában, a Délafrikai Köztársaságban is megtalálható egy repülő brigád (Flying Squad) nevű egység, azonban más feladatokat látnak el, mint a holland egység. A hollandoknál található rendőr járőrökkel lehetne őket összehasonlítani, hiszen a 30 egységből álló dél-afrikai csapat az ország egész területén a rendőrség munkáját segíti az emberi erőforrások bevetésével. Az egységek feladata a gyors mozgósítás sürgős, életveszélyes helyzetekben, amikor más rendőri egység nem tud reagálni a hívásra.

A dél-afrikai rendőrség nagy figyelmet fordít a közösséggel és a privát szektorral való együttmúködésre munkája során. 2011-ben elindítottak egy iskoláknak szóló programot, amelynek lényege, hogy a gyerekeket jobban megismertessék a helyi rendőrökkel, és felhívják a figyelmüket például a bűnözés és az erőszak egyénekre és családokra tett hatásaira, következményeire. Emellett a dél-afrikai rendőrség civil tartalékosokat is alkalmaz, amellyel a közösség rendfenntartásba történő szélesebb körü bevonására törekszik. ${ }^{22}$ Ezek a személyek a büntetlen elóélet mellett több kritériumnak is meg kell, hogy feleljenek, mielőtt bármilyen kiképzésen részt vennének. A tartalékosok önkéntes alapon, részmunkaidőben dolgoznak a rendőrségnek akár valamilyen műveleti feladat besegítésénél, akár más munkakörben szerzett készségeik felhasználásával. Hasonló szerepet töltenek be az Egyesült Királyságban látható közösségi támogató tisztek is, akik szintén a rendőrséghez tartoznak, azonban az egyenruhájuk is más, mint a rendőrtiszteké, hogy könnyen meg lehessen őket különböztetni. A délafrikai civil tartalékosoknak csak egy része hordhat egyenruhát, de ebben az esetben számukra is előírás a rendőrtisztektől való megkülönböztető jelvény hordása.

\footnotetext{
Ronald van Steden - Trevor Jones: Explaining the growth of plural policing: Comparing the Netherlands and Britain. 2010.

20 Johan Van Graan: Multi-sector cooperation in preventing crime: the case of a South African Neighbourhood Watch as an effective crime prevention model. Police Practice and Research, 17. (2016), 2. 136-148.

21 Police and defence. South African Government.

22 How to become a police reservist. South African Government.
} 


\subsection{Az önkormányzati rendészet, egyes rendészeti feladatokat ellátók összehasonlítása}

Magyarországon az önkormányzati rendészet feladatai közé tartozik a közterületek rendjének és tisztaságának fenntartása, illetve a tömegközlekedési eszközökön történő rendfenntartás is. ${ }^{23} \mathrm{~A}$ személyi állomány létszámával a rendőrség munkáját is segíti közös járőrözések során. Jelentős szerepük van a közösség biztonságérzetének megóvásában. Az állomány hivatalos személynek számít, és felhatalmazásuk van bizonyos kényszerítőeszközök alkalmazására, azonban kisebb hatáskörben, mint a rendőrségnek. A fővárosban, illetve a kerületekben kötelező, ezeken kívül azonban opcionális, hogy egy település szeretné-e a közterület-felügyelet megalakulását. ${ }^{24}$

Hasonló szerepben, mint Magyarországon a közterület-felügyelet, Angliában és Walesben megjelennek a korábban már említett közösségi támogató tisztek (community support officers vagy police community support officers), akik 2002-ben a rendőrség reformtörvényével egy új, polgári szerepet kaptak. ${ }^{25}$ Először Londonban vezették be ezt a kezdeményezést 2002-ben, mielőtt az egész országra kiterjedt ezeknek a tiszteknek az alkalmazása. Nem kapnak olyan kiképzést, mint a rendőrtisztek, és a kiképzés nem egységes a területi rendőrségek között, azonban a kiképzés után mindannyian egy 12 hónapos próbaidő elé néznek. A közösségi támogató tisztek nem jogosultak letartóztatni valakit, nem hallgathatnak ki fogvatartottakat, nem folytathatnak bűnügyi nyomozást, és nem végzik el az összetettebb, nagy kockázattal járó rendőrségi feladatokat sem, azonban mégis hatalmas szerepük van a közösség biztonságérzetének növelésében.

Csakúgy, mint Magyarországon a közterület-felügyelet, a közösségi támogató tisztek is segítik a rendőrök munkáját járőrözéssel, illetve 2003 óta bizonyos fix büntetéseket is kiszabhatnak. Ök nagyon fontos szerepet játszanak abban, hogy a helyi közösséggel egy fontos, bizalmi kapcsolatot létesítsenek. Angliában tapasztalható, hogy sok olyan tiszt van, akivel a közösségnek már egy jól múködő kapcsolata van, hiszen mindig látják őt a környéken. Ez egy bűneset jelentésénél, feldolgozásánál sokat jelenthet a sértettnek és a környezetének, máshogy fognak viszonyulni a tiszthez, mint egy vadidegen emberhez. Szintén fontos, hogy ezek a tisztek ismerni fogják a környék jellegzetességeit, illetve a közösségben újból és újból felbukkanó visszaeső bűnelkövetőket is.

2015-ben megjelent egy érdekes cikk a The Guardianben egy Essexben található kisvárosról, Frinton-On-Sea-ről. ${ }^{26}$ Ezen a településen nincsen rendőrség, csak 6 közösségi támogató tiszt áll alkalmazásban, akiknek még egy autó sem áll rendelkezésükre. Nagyjából 20 éve bezárt a helyi rendőrőrs ezen a 4000 lakosú településen, és valószínű a legközelebbi őrs is bezárásra fog kényszerülni, így több, mint 12 km-re lesz

\footnotetext{
23 Szabó László András: A migráció hatása a közigazgatásra. Magyar Rendészet, (2017), 1. 159-174.

24 Christián (2018) i. m. [71].

25 Crawford et alii (2005) i. m. 8.

26 Nadia Khomami: Frinton residents pay security firm to patrol streets. The Guardian, 2015.
} 
elérhető rendőr egy másik olyan településen, ahol sokkal magasabb a bűnözési ráta, mint Frinton-On-Sea-ben.

Emellett a helyi közösségből 300 lakó heti 2 fontot (nagyjából 800 forintot) fizet egy magánbiztonsági cégnek, hogy minden éjszaka este 7 és reggel 7 között járőrszolgálatot teljesítsenek a településen. Egy sürgősségi telefonvonal is a lakók rendelkezésére áll, de természetesen a segélyhívószámot is hívhatják, ha komoly bủncselekményről van szó.

A cég alkalmazásában álló biztonsági őröknek ugyanannyi joga van, mint egy átlagpolgárnak, nem alkalmazhatnak kényszerítőeszközöket, azonban a tapasztalataik szerint csupán a jelenlétük már érezhetően pozitívan hat a bűncselekmények megelőzésére a településen.

Vannak politikusok, akik aggodalmukat fejezték ki ezzel a módszerrel kapcsolatban, mondván, hogy inkább csak egy kicsivel több adót kéne fizettetni mindenkivel, amivel elérhetné a kormány, hogy több rendőrt alkalmazzon, és nem csak bizonyos társadalmi rétegek kiváltsága lenne az, hogy egy magánbiztonsági cégnek fizetve érik el a biztonságuk biztosítását.

A hollandoknál is megtalálható ez az önkormányzati rendészeti szerepkör, méghozzá több megnevezéssel is. 1989-ben elindult Hollandiában egy program, amely a régóta nem foglalkoztatott embereknek ajánlott munkalehetőséget. ${ }^{27} \mathrm{Ma}$ több ezer városi felügyelő (stadtswachten) áll alkalmazásban az ország több területén. Az önkormányzat biztosítja a munkájukat a városokon belül, és ôk egyenruhát is hordanak. Amszterdamban úgynevezett utcai oktatók (straatcoaches) állnak önkormányzati alkalmazásban. Egy magánbiztonsági cég biztosítja az embereket az önkormányzat számára, akiknek a fő feladata, hogy elsősorban az antiszociális viselkedés megakadályozását, kezelését segítsék. Ez a probléma legtöbbször a fiatalabb generációk körében kerül elő, és sokszor ezek az utcai oktatók ezeknek a fiataloknak a szüleivel próbálnak meg egy jó kapcsolatot kiépíteni, járőröznek az utcákon és beszélgetnek a helyiekkel. Az ő munkájuk talán leginkább az Egyesült Királyságban múködő közösségi támogató tisztek munkájára hasonlít. Munkájukat privát szociális dolgozók (home helpers) segítik, akiknek a szerepe akkor érvényesül, amikor a fiatal gondokozók szüleit kell meglátogatni. ${ }^{28}$ Fontos megemlíteni, hogy nekik nincsen kiterjedt hatáskörük, nem bírságolhatnak meg például senkit. Az egyik stratégia, amit használnak, hogy a fiatalokkal és a szüleikkel egy olyan egyezséget íratnak alá, ami a fiatalok problémás viselkedését helyezi a középpontba, és arra ajánl megoldást, hogy hogyan tudnak ezzel közösen megküzdeni. Ez a szülőknek is segítség, hogy tisztán lássák, hogy a gyermekeik milyen problémákkal állnak szemben.

Egy szintén amszterdami önkormányzati kezdeményezés a repülő brigád (Vliegende Brigades), akik rendőrségi tisztviselők, egészségügyi dolgozók és szociális munkások csapatából állnak össze. Hasonlóan, mint az utcai oktatók, az ő feladatuk is

\footnotetext{
Steden-Jones (2010) i. m.

28 Steden et alii (2016) i. m.
} 
az antiszociális viselkedés elleni fellépés, a közterületek biztonságának védelme és a kiszolgáltatott emberek segítése. Azonban a brigád tagjai a helyi önkormányzat egyenruhás alkalmazottai, és nekik van joguk büntetések kiszabására is. Az úgynevezett városi rendfenntartóknak (gemeentelijke toezichthouders en handhavers) szintén van felhatalmazása, hogy büntetéseket szabjanak ki kisebb szabályszegések elkövetése esetén.

\subsection{A társadalmi önkéntes bünmegelözési egyesületek összehasonlítása}

A Magyarországon múködő polgárőrség a rendőrség stratégiai partnereként funkcionál a közrend és a közbiztonság fenntartása érdekében. ${ }^{29}$ Feladatai közé tartozik a közterületeken való járőrszolgálat, illetve megfigyelőszolgálat ellátása. Jogos védelmi helyzetben, vegyi eszköz alkalmazása megengedett számukra. A polgárőrség mint társadalmi önkéntes bűnmegelőzési egyesület egy összehangolt, civil szervezetként működik az országban. Magyarországon nagyon fontos szerepet játszanak a közbiztonság fenntartásában, a járőrszolgálatok mellett rengeteg rendezvényt biztosítanak, manapság már részt vesznek az országhatárok védelménél is az illegális migráció megállításánál. Pintér Sándor belügyminiszter a 2019. évi Országos Polgárőr Szövetség küldöttgyúlésén kiemelte, hogy több roma polgárőrt kellene alkalmazni, amely nagyban hozzájárulhatna a hátrányos helyzetű térségek és a romák felzárkóztatásához is. ${ }^{30}$

A polgárőrség szervezete megjelenik az Egyesült Királyságban is. Rengeteg utca van, ahol látni a kihelyezett táblát, hogy egy polgárőrség által védett területen vagyunk épp. A kormány 2000-ben kezdett el olyan terveket támogatni, amelyek bizonyos lakóközösségekben több polgárőr elhelyezését biztosították, így hozzájárulva a látványosabb jelenlét megteremtéséhez. ${ }^{31}$ Manapság pedig már több olyan szervezet van, amelyek az állami támogatások nélkül múködnek. Hasonlóan, mint ahogy az önkormányzati rendészet bemutatásánál láthattuk, a polgárőrség munkája nagyban hozzájárul a helyi közösségek biztonságérzetének fenntartásához, hiszen számukra rendkívül fontos a lakókkal való jó kapcsolat kialakítása, amelyre a rendőrségnek sokszor egyszerűen nincs ideje.

Hollandiában a polgárőrség múködéséhez hasonló szervezetre példát Amszterdamban láthatunk. Amszterdam városában egy helyi biztonsági csapat múködik (buurtveiligheidsteam), amely a közösségen belüli közrend fenntartásáért felel. ${ }^{32}$ Ennek a szervezetnek a koordinációja az évszázad eleje óta egy rendkívül fontos feladat. ${ }^{33}$ A 217 szomszédság mindegyikében található egy koordinátor, akik úgy funkcionálnak,

\footnotetext{
Szabó (2017) i. m.

A polgárôrség biztonságot nyújt az országnak. 2019.

Crawford et alii (2005) i. m. 8.

Steden et alii (2016) i. m.

Steden-Jones (2010) i. m.
} 
mint egy helyi rendfenntartó tisztviselő. A fő feladatuk a bűnmegelőzés, azáltal, hogy jó kapcsolatot alakítanak ki a lakókkal, a helyi vállalkozásokkal, az önkormányzattal stb. A különböző csapatok néhol privát biztonsági őrökkel, gondnokokkal, fiatalokkal dolgozó munkásokkal egészülnek ki.

Érdekes példaként megemlíteném még a marokkói közösségi édesapákat (Marokkaanse buurtvaders), akik Amszterdamban és Hágában dolgoznak egy biztonságosabb környék megteremtése érdekében. A figyelmük középpontjában, hasonlóan, mint azt az önkormányzati rendészet célkitűzései közt láthattuk, csak kifejezetten a marokkói fiatalok által elkövetett antiszociális viselkedés megakadályozása és az ő szüleikkel való jó kapcsolat kiépítése áll.

A Dél-afrikai Köztársaságban már több városi területen bevezették a polgárőrség intézményét. ${ }^{34} \mathrm{Az}$ első ilyen program 1985-ben indult Johannesburgban. Van néhány része az országnak, ahol jobban múködik a koncepció, mint máshol, és ez valószínú, hogy a menedzsment minőségének, finanszírozási problémáknak, illetve a helyi közösség részvételi hajlandóságának köszönhető leginkább.

Nagyon érdekes a Roodepoortban létrejött roodekransi polgárőrség története, amely 2007-ben alakult, és ma már az ország egyik legnagyobb polgárőrségeként múködik. A szervezetben önkéntes civilek vesznek részt, akik a környékükön járőri munkát folytatnak, és bármilyen gyanús viselkedést a rendőrség, illetve a magánbiztonsági cégek munkatársai felé jeleznek. Az önkéntesekre úgy is lehet tekinteni, mint összekötő kapcsolat a helyi közösség és a rendőrség között, hiszen így tudják leginkább, hogy melyik utcákra/részekre kell még több járőr, hol láttak gyanúsan viselkedő embereket, illetve kik az új szomszédok, akik esetleg csatlakoznának a polgárőrség szervezetéhez. Nagyon sok helyi vállalkozás van, amely fontos szerepet játszik a város és a környék bűnözési rátájának a csökkentésében. Különböző felajánlásokkal segítenek, illetve például az egyik helyi templom a polgárőrség havi gyúlésének a helyszínét biztosítja.

\subsection{A magánbiztonság összehasonlítása}

Magyarországon az állam feladata a polgárai számára a biztonságot biztosítani, azonban ennek ellátásához nélkülözhetetlen bizonyos piaci alapon müködő szervezetek bevonása. ${ }^{35}$

A magánbiztonsági cégek feladatai olyan területeket fednek le, mint a személyés vagyonvédelem, a pénzszállítás/értékkísérés biztosítása, biztonságtechnikai rendszerek kiépítése, valamint ezek távfelügyelete. Idetartozik még a magánnyomozói tevekénységek lebonyolítása is. Szaktudással igyekeznek feladatukat ellátni, azonban hatalmas hátrány számukra, hogy nincs több jogosultságuk, mint egy átlagpolgárnak.

\footnotetext{
Van Graan (2016) i. m.

5 Szabó (2017) i. m.
} 
Az Egyesült Királyságban a magánbiztonsági őrök első nemzeti szabályozó szerve 2001-ben jött létre (Private Security Industry Act). ${ }^{36}$ Ez bevezette a biztonsági szervek hatóságát (Security Industry Act), amely az engedélyezés és a szabályozás területén fontos szerepet játszik, hiszen minden magánbiztonsági ellátónak náluk kell akkreditálni. Ezt a rendszert 2003-ban vezették be. Például a bejáratért felelős biztonsági őrök engedélyezését már 2004-ben megkezdték. Az engedély kiállításához szükséges feltétel egy erkölcsi bizonyítvány megszerzése és egy kötelező továbbképzés elvégzése is.

A magánbiztonsági őrök és a rendőrség kapcsolata néhány esetben problémás lehet azonban, főleg akkor, ha a biztonsági menedzserek volt rendőrök. Nagyon nagy hangsúly van a menedzserek informális hálózatán, hiszen ez meghatározza, hogy ki tudnak-e alakítani egy produktív együttmúködést a rendőrséggel.

A biztonsági szervek hatóságának elsődleges célja, hogy az iparág professzionalizmusát és minőségét javítsa, illetve, hogy elősegítse a magánbiztonsági cégek és a rendőrség között egy jó kapcsolat kibontakozását, amely hozzájárul a közösség szükségleteinek kielégítéséhez.

Az Egyesült Királysággal szemben Hollandiában sokkal kevésbé látványos növekedés volt megfigyelhető a magánbiztonság területén. ${ }^{37}$ A legújabb szabályozó törvényt 1997-ben adták ki (Wet particuliere beveiligingsorganisaties en recherchebureaus), amely a magánbiztonsági vállalatok és a magánnyomozói ügynökségek szabályozásáról szól. Ez a törvény még inkább megerősítette a magánbiztonsági cégek és az alkalmazottak szabályozását és továbbképzését, azonban szakmai körökben még így is vannak kétségek ennek a törvénynek a tényleges alkalmazásával szemben.

A Dél-afrikai Köztársaságban lévő magánbiztonsági cégek növekedése pedig az egyik legkiemelkedőbb a világon. ${ }^{38}$ Több magánszektor alkalmazásában álló biztonsági őr található az országban, mint rendőr. Egy 2017-es The Guardian-kutatás szerint azonban ez nem olyan meglepő, állításuk szerint a világ populációjának legalább a fele olyan országban él, ahol több magánbiztonsági őr áll alkalmazásban, mint rendőr. ${ }^{39}$ 2015-ben az Egyesült Királyságban 232 ezer privát biztonsági őrt vettek fel, míg ugyanebben az évben „csak” 151 ezer új rendőr került az állományba.

Ennek az iparágnak a szolgáltatásai között van a védelem, a felügyelet, a kíséret és a nyomozás feladata is mind cégek, mind magánszemélyek számára az ország egész területén.

A profit alapon múködő piac okozta verseny ellenére, manapság a különböző cégek alkalmazásában álló biztonsági őrök együttmúködnek egymással, így segítve a saját és mások munkáját is. Láthatjuk, hogy sok helyen pont a rendőri állomány hiánya hozza létre a közösségben azt a szükségletet, hogy máshonnan teremtsék meg a saját biztonságukat a lakóhelyükön.

\footnotetext{
36 Crawford et alii (2005) i. m. 8.

37 Steden-Jones (2010) i. m.

8 Van Graan (2016) i. m.

39 Claire Provost: The industry of inequality: Why the world is obsessed with private security. The Guardian, 2017.
} 


\section{Következtetések}

Ebben a cikkben szerettem volna felvázolni a Magyarországon és külföldön múködő olyan szerveket, amelyek a rendőrség mellett biztonságunk biztosításáért felelősek.

A magyar szervek mellett megemlítettük az Egyesült Királyságban, a Dél-afrikai Köztársaságban és a Hollandiában múködő modelleket is.

Látható, hogy míg a rendôrség felépítése eltérő lehet a kiválasztott országokban, sok hasonlóság is mutatkozik az önkormányzati rendészet és a társadalmi önkéntes bűnmegelőzési egyesületek feladatai között. Fontos cél ezeknél a szerveknél a közösség megismerése és egy jól múködő kapcsolat kialakítása mind a társadalommal, mind a helyi szervekkel.

Remélhetőleg demonstrálni tudtam, hogy a plural policing mint a rendvédelmi szervek, a rendvédelmi feladatokat ellátó szervek, az önkormányzatok, a magánbiztonsági vállalkozások és a társadalmi önkéntes bủnmegelőzési egyesületek együttes múködése a biztonság fenntartása érdekében valószínúleg egyre fontosabb téma lesz és egyre nagyobb szerepet fog kapni a biztonság körüli témák tárgyalása során. Christián László ezt a rendszert komplementer rendészeti rendszernek nevezte el, amely során az államot piaci és civil vállalkozások, egyesületek segítik egyes feladatainak elvégzése során. ${ }^{40}$

Azonban összességében még mindig sok megválaszolatlan kérdés és felfedezetlen terület van a plural policing területén. Még több kutatásra lenne szükség ahhoz, hogy ezt a komplex témát jobban megértsük.

Néhány kérdés, amivel érdemes lenne foglalkozni: Mennyiben járult hozzá a sebezhetőség érzése és a bűnözéstől való félelem a rendfenntartás megosztásához, az új rendfenntartó szervek létrejöttéhez? Hogyan járulnak hozzá a rendőrség mellett müködő új rendfenntartó szervek az állampolgárok biztonságérzetéhez és bizalmához ${ }^{41}$

\section{IRODALOMJEGYZÉK}

Biztonság - A magyar nyelv értelmező szótára. A Magyar Tudományos Akadémia Nyelvtudományi Intézete, 1959. Elérhető: www.arcanum.hu/hu/online-kiadvanyok/Lexikonok-a-magyarnyelv-ertelmezo-szotara-1BE8B/b-1EF8E/biztonsag-2119D/?list=eyJmaWx0ZXJzIjogeyJNVSI6IFsiTkZPX0xFWF9MZXhpa29ub2tfMUJFOEIiXX0sICJxdWVyeSI6ICJiaXp0b25zXHUwMGUxZyJ9 (A letöltés dátuma: 2020. 03. 24.)

Crawford, Adam - Stuart Lister - Sarah Blackburn - Jonathan Burnett: Plural policing: The mixed economy of visible patrols in England and Wales. Bristol, Policy Press, 2005.

Devroe, Elke - Jan Terpstra: Plural policing in Western Europe: a comparison. European Journal on Policing Studies, 2. (2015), 3. 235-244. Elérhető: https://openaccess.leidenuniv.nl/bitstream/handle/1887/33209/devroe\%20\%26\%20terpstra.pdf?sequence=1 (A letöltés dátuma: 2019. 12. 18.)

40 Christián (2018) i. m.

41 Elke Devroe - Jan Terpstra: Plural policing in Western Europe: a comparison. European Journal on Policing Studies, 2. (2015), 3. 235-244. 
Gazdag Ferenc - Tálas Péter: A biztonság fogalmának határairól. Nemzet és Biztonság, 1. (2008), 3-10. Elérhető: www.nemzetesbiztonsag.hu/cikkek/gazdag_ferenc_talas_peter-a_biztonsag_ fogalmanak_hatarairol.pdf (A letöltés dátuma: 2019.12.18.)

Péczeli Anna: A humán biztonság elmélete és gyakorlata Kanada és Japán példáján. 2012. Elérhető: www. grotius.hu/doc/pub/ESLRKT/2011_243_peczeli_anna_a_human-biztonsag_elmelete_es-gyakorlata.pdf (A letöltés dátuma: 2019. 12. 18.)

Steden, Ronald van - Trevor Jones: Explaining the growth of plural policing: Comparing the Netherlands and Britain. 2010. Elérhető: https://research.vu.nl/ws/portalfiles/portal/2738916/tekst+08+van+Steden+en+Jones+cahiers+16DEF.pdf (A letöltés dátuma: 2019. 12. 18.)

Steden, Ronald van - Jennifer Wood - Clifford Shearing - Hans Boutellier: The many faces of nodal policing: Team play and improvisation in Dutch community safety. Security Journal, 29. (2016), 3. 327-339. DOI: https://doi.org/10.1057/sj.2013.30

Szabó László András: A migráció hatása a közigazgatásra. Magyar Rendészet, (2017), 1. 159-174. Elérhető: http://real.mtak.hu/107778/1/Magyar_Rendeszet_2017_1_web-160-174.pdf (A letöltés dátuma: 2019. 12. 18.)

Van Graan, Johan: Multi-sector cooperation in preventing crime: the case of a South African Neighbourhood Watch as an effective crime prevention model. Police Practice and Research, 17. (2016), 2. 136-148. DOI: https://doi.org/10.1080/15614263.2015.1128159

\section{Jogforrások}

1998. évi törvény: Crime and Disorder Act. Elérhető: www.legislation.gov.uk/ukpga/1998/37/contents (A letöltés dátuma: 2020. 05. 25.)

1994. évi XXXIV. törvény a Rendőrségről. Elérhető: https://net.jogtar.hu/jogszabaly?docid $=99400034 . t v$ (A letöltés dátuma: 2020. 05. 25.)

1994. évi törvény: Police and Magistrates' Courts Act. Elérhető: www.legislation.gov.uk/ ukpga/1994/29/part/I/chapter/I/enacted (A letöltés dátuma: 2020. 05. 25.)

\section{Internetes források}

British Transport Police. Elérhető: www.btp.police.uk (A letöltés dátuma: 2019. 12. 18.)

Christián László: Rendészeti szervek. In Jakab András - Fekete Balázs szerk.: Internetes Jogtudományi Enciklopédia. Alkotmányjog rovat, 2018. Elérhető: http://ijoten.hu/szocikk/rendeszeti-szervek (A letöltés dátuma: 2019. 12.18.)

Crime and policing in England, Wales and Northern Ireland, List of UK police forces. Elérhető: www.police. uk/forces/ (A letöltés dátuma: 2019. 12. 18.)

How to become a police reservist. South African Government. Elérhető: www.gov.za/services/lookingemployment/how-become-police-reservist (A letöltés dátuma: 2020. 05. 25.)

Khomami, Nadia: Frinton residents pay security firm to patrol streets. The Guardian, 2015. Elérhetô: www.theguardian.com/uk-news/2015/nov/03/seaside-town-residents-frinton-pay-securityfirm-patrol-streets (A letöltés dátuma: 2019. 12. 18.)

Organisation of the Dutch police. Government of the Netherlands. Elérhető: www.government.nl/topics/police/organisation-of-the-dutch-police (A letöltés dátuma: 2020. 05. 25.)

A polgárôrség biztonságot nyújt az országnak. 2019. Elérhető: www.origo.hu/itthon/20190412-pinter-a-polgarorseg-biztonsagot-nyujt-az-orszagnak.html (A letöltés dátuma: 2019. 12. 18.)

Police and defence. South African Government. Elérhető: www.gov.za/about-sa/police-and-defence\#reservist (A letöltés dátuma: 2020. 05. 25.) 
Provost, Claire: The industry of inequality: Why the world is obsessed with private security. The Guardian, 2017. Elérhető: www.theguardian.com/inequality/2017/may/12/industry-of-inequalitywhy-world-is-obsessed-with-private-security (A letöltés dátuma: 2019. 12. 18.)

\title{
ABSTRACT
}

\section{Plural Policing: a Comparison of the Hungarian and Foreign Agencies Responsible for Providing Security}

\author{
Laura SCHMIDT
}

The aim of this article is to demonstrate who is responsible, alongside the police, for providing security both in Hungary and abroad. The police forces, community support officers, the private security business and other agencies in Hungary will be compared to the agencies operating in the United Kingdom, and the agencies in the South African Republic and the Netherlands will also be explored. There are some differences in the chosen countries, however, we can also see similarities between the duties of the community support officers as well as the people volunteering for neighbourhood watches. The system of plural policing has a growing role in Hungary and abroad for maintaining security and preventing crimes. Therefore, it is essential to have more information about the outline and the working of this model.

Keywords: security, private security, law enforcement, plural policing. 